\title{
Local Rating Systems for Sustainability are Mandatory to Protect the Planet - LEED in the Middle East
}

\author{
Wael Ahmed Shaaban Abo Neama \\ Architectural Department, Faculty of Fine Arts, \\ Helwan University, Zamalek, Cairo, Egypt \\ wael.aboneama@gmail.com, wael.shaaban@ecgsa.com
}

\begin{abstract}
Sustainable design becomes a mandatory as a result of environmental requirements. Furthermore, LEED as a rating system has started to be a tool in many countries in the world. The research objective is to push all architects to protect the environment through their architectural designs by applying the most effective sustainable criteria. The methodology will be focused on evaluating LEED in the Middle East compared with a local rating system. The outcome will be focused on the importance of creating a rating system for each region, which considers local environmental challenges.
\end{abstract}

Keywords: Rating systems; Sustainability, Protect the Planet; LEED in the Middle East.

eISSN 2514-751X @ 2018. The Authors. Published for AMER ABRA cE-Bs by e-International Publishing House, Ltd., UK. This is an open-access article under the CC BY-NC-ND license (http://creativecommons.org/licenses/bync-nd/4.0/). Peer-review under responsibility of AMER (Association of Malaysian Environment-Behaviour Researchers), ABRA (Association of Behavioural Researchers on Asians) and cE-Bs (Centre for EnvironmentBehaviour Studies), Faculty of Architecture, Planning \& Surveying, Universiti Teknologi MARA, Malaysia.

https://doi.org/10.21834/aje-bs.v3i8.286 


\subsection{Introduction}

Each rating system developing meets the following underlying principles: ${ }^{(1)}$

1) Ensure environmental quality through an accessible, holistic, and balanced measure of environmental impacts.

2) Measuring environmental quality.

3) Quantifying and calibrating a cost-effective performance standard for defining environmental quality.

4) Reflect the social and economic benefits of meeting the environmental objectives covered.

5) Provide a common framework of assessment that is tailored to meet the 'local' context, including regulation, climate, and sector.

Based on above items, we can recognize that regional environmental challenges are the most important items to have a rating system. Each part of the world is suffering from lack of one or more resources. That means any region of the world will have specific credits, which measure the environmental priorities and challenges. Besides, it will have some general credits that serve the global challenges.

\subsection{Research Problem}

The procedures of getting a LEED certificate are based on collecting points and achieving some very few prerequisites. After studying all prerequisites, we will find no one of them is focused on the regional environmental problems even in the US. The problem focuses on collecting points regardless the importance of this point to the environment.

\subsection{Methodology}

The methodology focuses on comparing the LEED principals as rating system with local one, which is Green Pyramid. The comparison will evaluate each principal against local environmental changes and clarify the need of using local sustainable rating system for each region.

\section{Sustainable Design Concept in LEED as Rating System}

The sustainable design concept is based on specific design structures that reduce the overall negative impact of the built environment on human and the natural environment through ${ }^{(2)}$.

1) Efficiently using energy, water, land, and materials.

2) Protecting occupant health and improving employee productivity

3)Reducing waste and pollution from each green building.

\footnotetext{
(1) BRE. BREEAM New Construction, Non-Domestic Bullings, Technical Manual.2011. (SO5073 - V.2.00), p.13

${ }^{(2)}$ Green Building Education Services, LEED Green Associate study guide, 2010
} 


\section{Sustainable Design Categories in LEED \& Local Rating System}

Hereby, it will be presented LEED and Green Pyramid categories tables (1) and (2). The word phrasing is the same in both with different weight and both have 110 points.|

\begin{tabular}{lll}
\multicolumn{3}{c}{ Table 1: LEED categories \& their Weighting } \\
\hline LEED Categories & Category weighting & Percentage \\
\hline Sustainable sites & 26 points & $(23.6 \%)$ \\
Water efficiency & 10 points & $(9.1 \%)$ \\
Energy \& Atmosphere & 35 points & $(31.8 \%)$ \\
Material \& Resources & 14 points & $(12.7 \%)$ \\
Indoor Environmental Quality & 15 points & $(13.6 \%)$ \\
Innovation in Design & 6 points & $(5.6 \%)$ \\
Regional priority & 4 points & $(3.6 \%)$ \\
SUM & 110 points & $(100 \%)$ \\
\end{tabular}

Table 2: Green Pyramid Categories \& their Weighting ${ }^{(3)}$

\begin{tabular}{lll}
\hline Green Pyramid Categories & Category weighting & Percentage \\
\hline Sustainable Site, Accessibility, Ecology & 15 points & $(13.6 \%)$ \\
Water efficiency & 30 points & $(27.3 \%)$ \\
Energy Efficiency & 25 points & $(22.7 \%)$ \\
Material \& Resources & 10 points & $(9.1 \%)$ \\
Indoor Environmental Quality & 10 points & $(9.1 \%)$ \\
Innovation and Added Value & 10 points & $(9.1 \%)$ \\
Management & 10 points & $(9.1 \%)$ \\
SUM & 110 points & $(100 \%)$ \\
\hline
\end{tabular}

Tables (1) and (2) clarify the need of a local rating system for each region. However, both have approximately the same categories but the weight of each category reflects the importance and the need of each region for it. For example, Water Efficiency has only $(9 \%)$ in LEED, howeverithas (27\%) in Green Pyramid. It means that Egyptis worried about the suffering of draught. Each part of the world should define its problems based on itself environmental and ecological studies to set the attributes of its rating system.

\footnotetext{
(2) Green Building Education Services, LEED Green Associate study guide \& LEED Checklist, 2010

(3) The Housing and Building National Research Centre, The Green Pyramid Rating System, First Edition - April 2011,

for public review (First Revision: following Draft document dated May 2010)
} 


\section{Category One: Sustainable Sites}

Sustainable Sites as a statement in LEED includes its goal to protect the virgin lands from human attacks.

\section{Sustainable sites Prerequisite, Credits \& their points:}

The only prerequisite is "Construction Activity Pollution Prevention"and the following are its credits Table. 3

Table 3: Sustainable Sites Credits \& their Weighting ${ }^{(2)}$

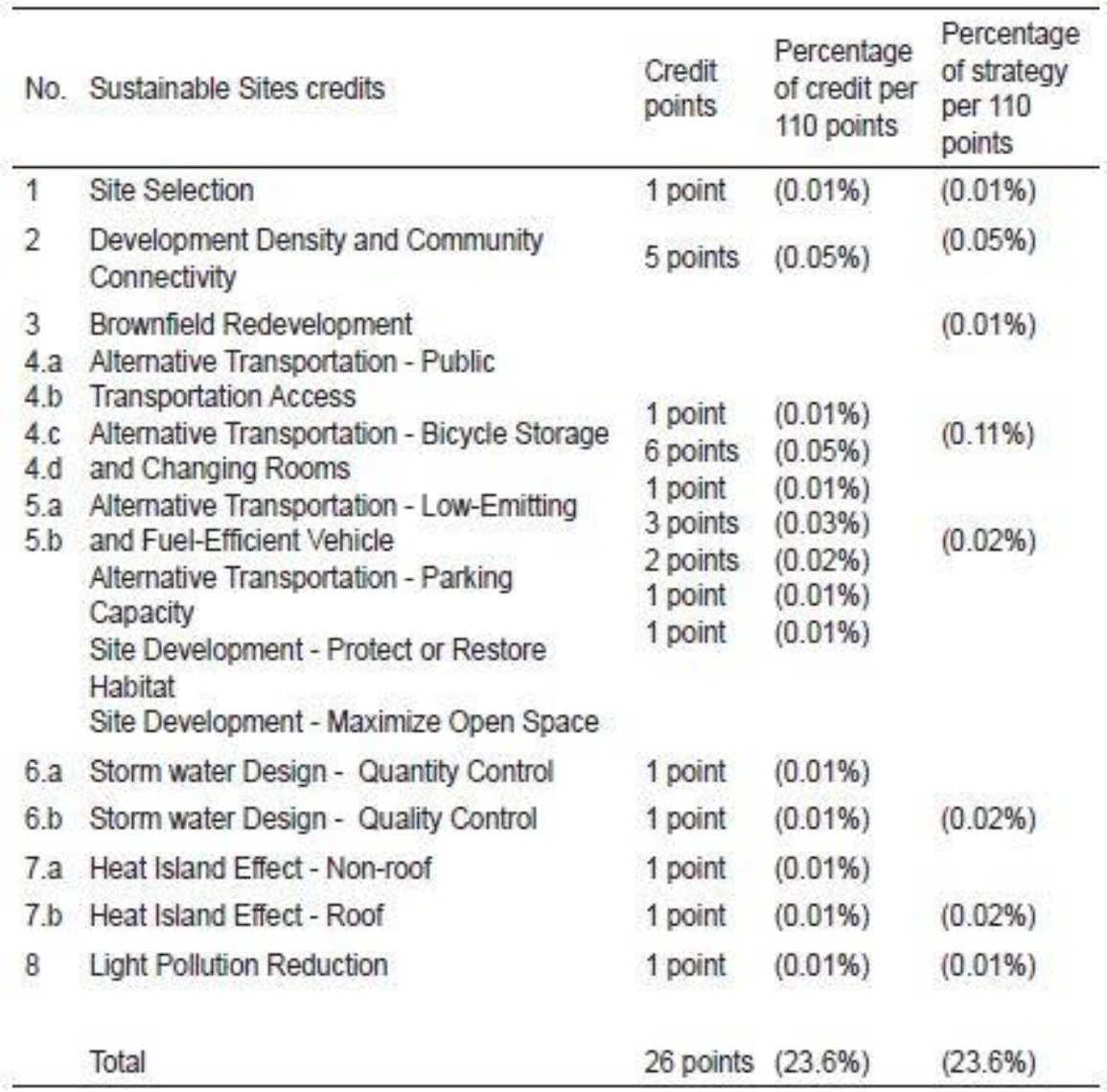

The following part of the research will describe briefly Sustainable Sites credits in LEED and their impact on the Middle East region: 


\section{Protect undeveloped land "Greenfield"}

1) Avoid building on prime farmland, wetlands, public parks, areas of the flood plain, areas close to lakes, streams, or habitat for threatened, areas that are used by organisms for their life cycle.

2) Make the building dense by minimizing the project footprint.

Nobody can deny that the previous strategies can protect the ecological system in any part of the world include the Middle East except the last one which requires to minimize the footprint. Refer to Fig. 1. We can see that historical places in the Middle East were against this concept. This is the same phenomena of window type "Mashrabia." This strategy is obvious for countries, which have open green spaces with forests. That means even in the Middle East region we can't have only one rating system.
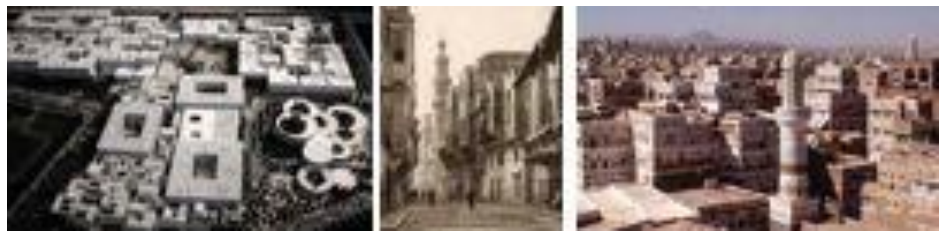

Figure 1: (a) Picture on the left side illustrates Naseem in Doha; (b) picture in the middle ofold Cairo;(c) picture onthe rightillustratesYemen planning (3)(3)http:// ad009cdnb.archdaily.netlwp-contentluploads/2009107106_alnasseem-528x396.jpg http://3.bp.blogspot.com/_RNrl2GroVwl/TSqNiBsG3Cl/AAAAAAAADn4/ jvLkzZZ7Gxg/s1600/old\%2Bcairo.jpg

http://spacingtoronto.ca/wp-content/uploads/2012/03/2271829554_4675283ec5 z-600x400.jpg

\section{Reuse I Restore Previously Developed Sites "Brownfield"}

1) Develop brown field sites and using existing transportation.

2) Restore damaged areas.

3) Provide community connectivity by locating near basic services ${ }^{*}$.

\section{Reduce Automobile uses or Promote Alternatives}

Such as car share Program, enhance transportation, bicycle accessibility, alternative fuel vehicle, and minimize parking lots.

\section{Develop Efficient Storm Water Management}

Such as reducing impervious surfaces, collect storm water and reuse it, and reduce erosion because water running off.

\footnotetext{
- Basic services: are those services that are open to the public, and are common services that people might use regularly. People must be able to walk between the project and the services without being blocked by walls, highways, or other barriers (this is called pedestrian access). LEED encourages building near a variety of basic services, not just one type of service. The basic- services such as: Bank, Masjid, Supermarket / convenience store, Day care, Dry cleaner, Fire station, Salon, Hardware store, Library, Medical / Dental, Park, Pharmacy, Post office, Restaurant, School, Theatre,

Museum. Community centre. Grm. Church
} 


\section{Reduce Heat Islands *Effect}

Heat Islands are negatively affecting the ecology system Fig. 2. LEED considers the following:

1) Minimize the development footprint.

2) Hardscape materials with high reflectance and Covering roofs with high SRI ${ }^{* *}$ materials or Green roofs.

3) Open grid paving.
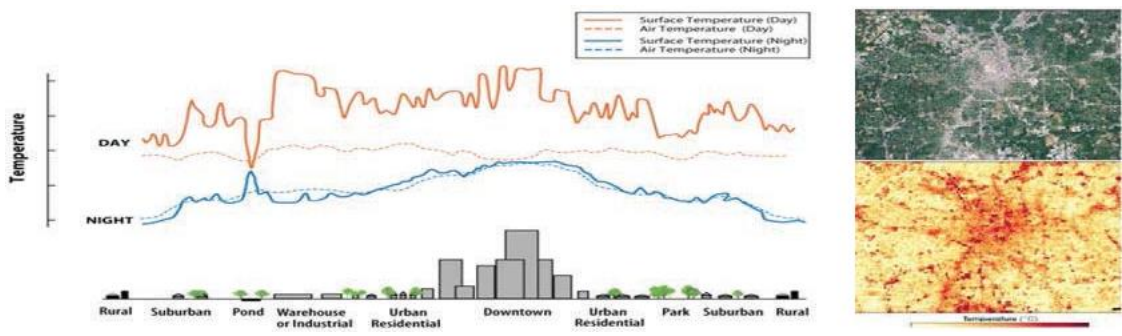

Fig.2.(a)Diagramonleftillustratesthetemperature differencebetweenurbanandnatural areas; (b) picture on rightaboveillustratesanormal aerial viewfor a village;(c) picture on rightbelowillustrates thermal massesfor picture(b). "Reference:(2)"

\section{Reduce Light Pollution}

The proper lighting design will result in levels that both ensure safety and reduce light pollution.

\section{Conclusion of Sustainable Sites Strategies in the Middle East Region:}

Most of the Sustainable Sites strategies can protect the planet through protecting Green fields from human attack by construction. On the other hand, the weight of each item should be revised against local environmental and ecological challenges.

\section{Category Two: Water Efficiency}

It aims to protect potable water resources and to reduce the need for treatment of wastewater.

\section{Water Efficiency Prerequisite, Credits\& their Points:}

The prerequisite is (water use reduction by $20 \%$ ). Table 4 describe its credits:

\footnotetext{
- Heat Islands: are the temperature differences between developed and undeveloped areas. Also, it Changes rain patterns

-SRI "Solar Reflectance Index" is the surface material ability to reflect sunlight on scale 1 to 0 . Black is Zero and white is one. That is why white material is better than black one
} 
Table 4: Water Efficiency Credits \& their Weighting ${ }^{(2)}$

\begin{tabular}{llll}
\hline No. Water Efficiency credits & Credit points & $\begin{array}{l}\text { Percentage for credit } \\
\text { per } 110 \text { points }\end{array}$ \\
\hline 1 & Water Efficient Landscaping & 4 points & $(0.04 \%)$ \\
2 & Innovative Waste Water Technologies & 2 points & $(0.02 \%)$ \\
3 & Water Use Reduction & 4 points & $(0.04 \%)$ \\
& Total & 10 points & $(0.09 \%)$ \\
\hline
\end{tabular}

\section{Outdoor Water Reduction Practice}

1) Landscape Design: to select plants native adaptive ${ }^{* *}$ plants ${ }^{*}$ and avoid invasive plants ${ }^{* * *}$. 2) Xeriscaping: is the type of landscaping that reduces or eliminates the need for supplemental irrigation.

\section{Use Storm Water, Gray Water, \& Processed Water}

Storm Water or (Reclaimed rainwater) can be controlled with a roof top collection system. See Fig. 3.
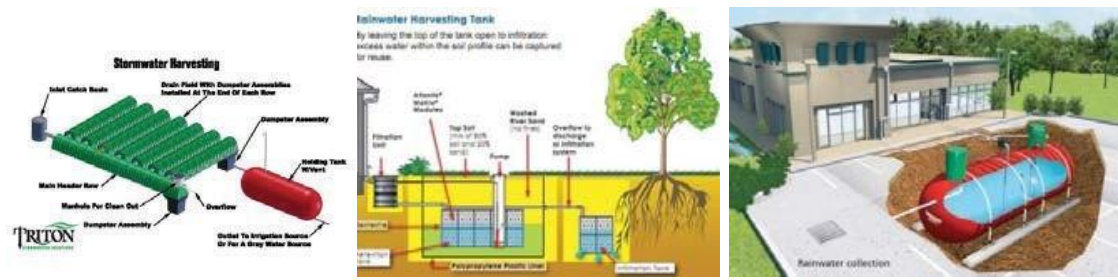

Figure 3: (a) Picture on Left Illustrates the Idea of Rooftop Storm Water Harvesting;

(b) Picture in the Middle Illustrate the Reclaiming Process of Storm Water;

(c) Picture on Right for Storm Water Tank. ${ }^{(4)}$

1. Gray Water is untreated household wastewater. It could be used for irrigation and landscape. See Fig. 4.

\footnotetext{
"Adaptive plants are non-native plants but they perform well in the local climate. They require less water and more disease resistance

- Native plants grow naturally and require less water, fertilizer

"'Invasive plants grow quickly and aggressively, spreading and displacing other plants

(4) http://www.tritonsws.com/images/downloads/33-complete-stormwater-harvesting-front.jpg

http:/capitolgreenroofs.groupsite.com/uploads/files
} 

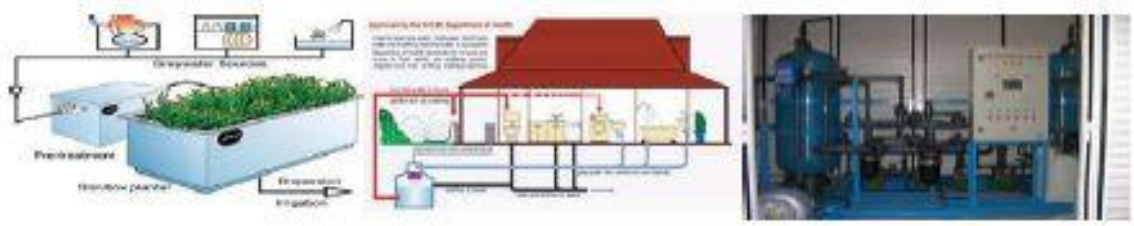

Figure 4: (a)Picture on left \& (b) picture in the middle illustrate the source and using ofgraywater; (c)pictureon therightforgraywatertreatment. ${ }^{(5)}$

\section{Indoor Strategies to Save Water}

LEED strategies for saving indoor water consuming such are; dual flush toilets, high efficiency toilets, waterless Urinals, composite toilet system, low-flow showerhead and faucets, faucets with low-flow aerator and/or motion sensor, and install water meter

\section{Conclusion of Water Efficiency Strategies in the Middle East Region:}

All LEED water efficiency strategies help to save water consumption and generate new resources for water; however, these resources such as storm water rarely to be found in the Middle East. The weight of water efficiency in LEED does not reflect the real need of water in the Middle East region. In addition, new credits should be added. There are techniques for absorbing water from air moisture. Other techniques like using the solar energy for desalination of seawater without using any fossil energy.

\section{Category Three: Energy \& Atmosphere}

It aims to reduce energy consumption for low $\mathrm{CO} 2$ emissions and to protect the planet and the ecological system by using natural refrigerants.

\section{Energy \& Atmosphere Prerequisites, Credits \& their Points:}

There prerequisites are; fundamental commissioning of building energy systems; minimum energyperformance; andfundamental refrigerant management Table 5.

\section{Energy \& Atmosphere Goals in LEED:}

1) Reduce energy consumption.

2) Energy Audit

3) Building Orientation

4) Building Envelops: $40 \%$ of energy used to heat and cool was lost to air for leaks in building envelopes or wrong glass type.

\footnotetext{
(5) http://graywater.com/soilb.jpg http://udcinc.rog/graywaterlarge.jpg

(2) Green Building Education Services, LEED Green Associate study guide \& LEED Checklist, 2010
} 
5) Lighting Design: to select the proper lighting fixture with minimum energy consumption and using lighting controls.

6) HVAC system: it counts $30 \%$ of energy in commercial building and $50 \%$ of energy in residential.

7) Use renewable energy.

8) Protect the Ozone layer.

Table 5: Energy \& Atmosphere Credits \& their Weighting ${ }^{(2)}$

\begin{tabular}{llll}
\hline No. & Energy \& Atmosphere credits & Credit points & $\begin{array}{l}\text { Percentage for credit } \\
\text { per } 110 \text { points }\end{array}$ \\
\hline 1 & Optimize Energy Performance & 19 points & $(0.17 \%)$ \\
2 & On-site Renewable Energy & 7 points & $(0.06 \%)$ \\
3 & Enhanced Commissioning & 2 points & $(0.02 \%)$ \\
4 & Enhanced Refrigerant Management & 2 points & $(0.02 \%)$ \\
5 & Measurement and Verification & 3 points & $(0.03 \%)$ \\
6 & Green Power & 2 points & $(0.02 \%)$ \\
& & & \\
& & 35 points & $(0.32 \%)$ \\
\hline
\end{tabular}

\section{Conclusion of Energy \& Atmosphere Strategies in the Middle East Region:}

It leads to better energy efficiency, to protect the Ozone layer and minimize the GWP. ${ }^{*}$ In the Middle East, we should emphasize on using available renewable-energy resources. We still use electricity and natural gas for water heating. Local rating systems should guarantee to protect natural resources.

\section{Category Four: Material \& Resources}

Sustainable Materials are materials, which reduce the demands on ecosystems during their life cycle. It includes the material processing and the entire product life cycle through use and disposal. This category aims to reduce waste and to build with sustainable materials.

\section{Material \& Resources Prerequisites, Credits \&their Points:}

The prerequisite is; storage and collection of recyclables.

\section{Conclusion of Material \& Resources Strategies in the Middle East Region:}

This category helps to reduce the demand for new materials by reusing buildings and materials when possible. Furthermore, it recommends using renewable and local materials besides

\footnotetext{
- GWB means Global Warming Potential

(2) Green Building Education Services, LEED Green Associate study guide \& LEED Checklist, 2010
} 
enhancing recycling programs.

Table 6: Materials and Resources Credits \& their Weighting ${ }^{(2)}$

\begin{tabular}{|c|c|c|c|c|}
\hline No. & Materials \& Resources credits & $\begin{array}{l}\text { Credit } \\
\text { points }\end{array}$ & $\begin{array}{l}\text { Percentage } \\
\text { of credit per } \\
110 \text { points }\end{array}$ & $\begin{array}{l}\text { Percentage } \\
\text { of strategy } \\
\text { per } 110 \\
\text { points }\end{array}$ \\
\hline 1 & $\begin{array}{l}\text { Building Reuse - Maintain Existing Walls, } \\
\text { Floors, and Roofs }\end{array}$ & 3 points & $(0.03 \%)$ & \\
\hline 1.a & $\begin{array}{l}\text { Building Reuse - Maintain } 50 \% \text { of Interior } \\
\text { Nonstructural Elements }\end{array}$ & 1 points & $(0.01 \%)$ & $(0.04 \%)$ \\
\hline 2 & Construction Waste Management & 2 points & $(0.02 \%)$ & $(0.02 \%)$ \\
\hline 3 & Materials Reuse & 2 points & $(0.02 \%)$ & $(0.02 \%)$ \\
\hline 4 & Recycled Content & 2 points & $(0.02 \%)$ & $(0.02 \%)$ \\
\hline 5 & Regional Materials & 2 points & $(0.02 \%)$ & $(0.02 \%)$ \\
\hline 6 & Rapidly Renewable Materials & 1 point & $(0.01 \%)$ & $(0.01 \%)$ \\
\hline \multirow[t]{2}{*}{7} & Certified Wood & 1 point & $(0.01 \%)$ & $(0.01 \%)$ \\
\hline & Total & 14 points & $(12.7 \%)$ & $(12.7 \%)$ \\
\hline
\end{tabular}

\section{Category Five: Indoor Environmental Quality}

1) Improve Indoor Air Quality (IAQ) by avoiding using materials, which have high VOCs.

2) Improve ventilation.

3) Control air temperature; humidity; lighting; acoustics; and air quality.

Indoor Environmental Quality Prerequisites, Credits\& their points: There are two prerequisites for Indoor Environmental Quality (IAQ), which are; minimum indoor air quality performance and environmental Tobacco smoke (ETS) control.

Conclusion of Indoor Environmental Quality Strategies in the Middle East region:

The credits for ventilation, daylights are important in any environment; however, in the Middle East credits should focus on indoor courts. It means that for hot weather countries the indoor environmental quality principals are different from cold-weather countries.

\section{Category Six: Innovation and Design Process}

Innovation in design or operating existing building is a flexible category used to award points for performance and creativity. It is used for:

\footnotetext{
(2) Green Building Education Services, LEED Green Associate study guide \& LEED Checklist, 2010

- VOC means Volatile Organic Compounds
} 
7: Indoor Environmental Quality Credits \& their Weighting ${ }^{(2)}$

\begin{tabular}{|c|c|c|c|c|}
\hline No. & $\begin{array}{l}\text { Indoor Environmental Quality } \\
\text { credits }\end{array}$ & Credit points & $\begin{array}{l}\text { Percentage of } \\
\text { credit per } 110 \\
\text { points }\end{array}$ & $\begin{array}{l}\text { Percentage of } \\
\text { strategy per } \\
110 \text { points }\end{array}$ \\
\hline 1 & Outdoor Air Delivery Monitoring & 1 point & $(0.01 \%)$ & $(0.01 \%)$ \\
\hline 2 & Increased Ventilation & 1 point & $(0.01 \%)$ & $(0.01 \%)$ \\
\hline 3.a & $\begin{array}{l}\text { Construction IAQ Management } \\
\text { Plan - During Construction }\end{array}$ & 1 point & $(0.01 \%)$ & \\
\hline 3.b & $\begin{array}{l}\text { Construction IAQ Management } \\
\text { Plan-Before Occupancy }\end{array}$ & 1 point & $(0.01 \%)$ & $(0.02 \%)$ \\
\hline 4.a & $\begin{array}{l}\text { Low - Emitting Materials - } \\
\text { Adhesives and Sealants }\end{array}$ & 1 point & $(0.01 \%)$ & \\
\hline 4.b & $\begin{array}{l}\text { Low - Emitting Materials - Paints } \\
\text { and Coatings }\end{array}$ & 1 point & $(0.01 \%)$ & \\
\hline 4.c & $\begin{array}{l}\text { Low - Emitting Materials - Flooring } \\
\text { Systems }\end{array}$ & 1 point & $(0.01 \%)$ & \\
\hline 4.d & $\begin{array}{l}\text { Low - Emitting Materials - } \\
\text { Composite Wood and Agrifiber } \\
\text { Products }\end{array}$ & 1 point & $(0.01 \%)$ & $(0.04 \%)$ \\
\hline 5 & $\begin{array}{l}\text { Indoor Chemical and Pollutant } \\
\text { Source Control }\end{array}$ & 1 point & $(0.01 \%)$ & $(0.01 \%)$ \\
\hline $6 . \mathrm{a}$ & Controllability of Systems - Lighting & 1 point & $(0.01 \%)$ & \\
\hline 6.b & $\begin{array}{l}\text { Controllability of Systems - } \\
\text { Thermal Comfort }\end{array}$ & 1 point & $(0.01 \%)$ & $(0.03 \%)$ \\
\hline 7.a & Thermal Comfort - Design & 1 point & $(0.01 \%)$ & \\
\hline 7.b & Thermal Comfort - Verification & 1 point & $(0.01 \%)$ & $(0.03 \%)$ \\
\hline $8 . a$ & Daylight and Views - Daylight & 1 point & $(0.01 \%)$ & \\
\hline 8.b & Daylight and Views - Views & 1 point & $(0.01 \%)$ & $(0.02 \%)$ \\
\hline & Total & 15 points & $(13.6 \%)$ & $(13.6 \%)$ \\
\hline
\end{tabular}

Exemplary performance that exceeds the credit requirements.

1) Innovative performance.

2) Having one LEED AP*.

\section{Conclusion of Innovation and Design in the Middle East Region:}

It is an important category for any rating system. However, it should have more points for innovation in building performance, especially for cooling in hot weather.

(2) Green Building Education Services, LEED Green Associate study guide \& LEED Checklist, 2010

-AP means Accredit Professional 


\section{Category Seven: Regional Priority}

Regional priority credits are only available for projects within the USA.

\section{Conclusion of Regional Priority in the Middle East Region:}

Regional priority credits have nothing to be mentioned in the Middle East countries because they are only available in the USA. However, this category can solve many troubles in LEED as an international rating system.

\subsection{Conclusion}

The research has explored that using LEED, as a rating system in any part of the world is not the best way to achieve the sustainability level for some parts of the world. LEED credits weight reflects the need of an entire environment, which is not in the Middle East. On the other hand, Green Pyramid as the local rating system has missed some important areas of Egyptian environment. It needs a lot of development to enhance its role.

\subsection{Research Recommendations}

1) Architects have a big role to protect our planet through following sustainable principals during the design and construction processes.

2) Each part of the world has its environmental challenges that architects should consider by their designs.

3) LEED is an effective sustainable tool that architects can use, but not everywhere. It measures based on the USA environmental challenges which are not implemented in the Middle East.

4) Architects should consider the Middle East countries environmental challenges. Some of those are not mentioned in LEED. Local environmental criteria should be applied to any rating system to can be fully effective and reflect the environment of the project.

5) Local sustainable rating systems should be applied for building permits. Authorities in Middle East countries should require from architects to follow it as a mandatory requirement. Otherwise, owners will not be careful to ask architects to have sustainable buildings to protect our environment.

\section{Acknowledgment}

The researcher really appreciates and wishes to thank architectural department, faculty of Fine Arts, Helwan University in Cairo, Egypt for its efforts to support this research. The researcher has deeply appreciated the efforts of Prof. Dr. Fatma Al-Nabaweya Mohammad Abdu El-Quesny, Botany in National Research Center, Giza, Egypt, and architect Reem Hesham Mohammad Namera for their help to push this research steps forward by data collection. 


\section{References}

AmyVdes(2001). HandbookofWaterUseandConservation. WaterPlow press. Amherst, MA. p. 140.

BRE. BREEAM New Construction, Non-Domestic Buildings, Technical Manual.2011. (SD5073 - V.2.00), p.13

http://en.wikipedia.org/wiki/Sustainability http://www.usgbc.org http://www.wbdg.org/resources/greenroofs.php

The Housing and Building National Research Centre, The Green Pyramid Rating System, First Edition - April 2011, for public review (First Revision: following Draft document dated May 2010)

United States Department ofEnergy, "Energy Consumption Characteristic of Commercial Building HVAC Systems, Volume III: Energy Savings Potential" (PDF).

United States Green Building Council, Green Building Education Services, LEED Green Associate study guide, 2010.

United States GreenBuilding Council, Green Building EducationServices, Checklist for LEED for New Constrcution \& Major Development

- Docs5719, 2010.

United States Green Building Council, Green Building Education Services, LEED Green Associate study guide, 2010. 